\title{
CLINICAL AND PATHOGENETIC PECULIARITIES OF SEXUAL DISORDERS IN MEN WITH HYPERTENSION AND WAYS OF THEIR CORRECTION
}

\section{КЛІНІКО-ПАТОГЕНЕТИЧНІ ОСОБЛИВОСТІ СЕКСУАЛЬНИХ РОЗЛАДІВ У ЧОЛОВІКІВ, ХВОРИХ НА АРТЕРІАЛЬНУ ГІПЕРТЕНЗІЮ, ТА ШЛЯХИ ЇХ КОРЕКЦЇ̈}

\section{Vintoniv Oksana ${ }^{1}$}

DOI: http://dx.doi.org/10.30525/978-9934-571-31-2_3

Abstract. Thesis for searching of the degree in Medical Sciences on specialty 14.01.06 - Urology. -- State Institution "Institute of Urology of the National Academy of Medical Sciences ofUkraine", - Kyiv, 2015.

The Dissertation is devoted to solving the current issues in urology improving diagnosis and treatment efficacy sexual disorders in men with hypertension by correction of complex changes with regard to health. This paper analyzes the comprehensive examination and treatment of 120 patients with sexual disorders on the background AG. Patients were divided into 4 groups: I group (30 patients) - treated with phosphodiesterase-5 inhibitor such as sildenafil "on demand"; II group (30 patients) - received sildenafil $50 \mathrm{mg}$ a day; III group (30 patients) - sildenafil $50 \mathrm{mg}$ a day plus arginine; IV group (30 patients) - sildenafil + Arginine + LNP-therapy (local negative pressure therapy with electrical fotovacuum stimulation on the machine "Lodap").

The study proved and proposed new medical diagnostic algorithm based on the method of combination therapy sildenafil + arginine + LNP-fotovacuum electrical stimulation therapy to correct sexual disorders in men suffering from hypertension. The use of sildenafil, arginine and local negative pressure therapy with fotovacuum electrical stimulation in patients with sexual disorders on a background of hypertension leads to an improvement of the disease, is safe, affordable and not accompanied by side effects.

${ }^{1}$ Assistant of the Department of Urology,

SHEI «Ivano-Frankivsk National Medical University», Ukraine 


\section{1. Вступ}

Проблема надання спеціалізованої допомоги чоловікам із сексуальними розладами має велике медико-соціальне значення, актуальність якої зростає упродовж останніх років [3, с. 74]. Адже сексуальне здоров'я $є$ важливим компонентом при оцінці його загального стану, що погіршується в силу багатьох причин. Частота відомих несприятливих факторів ризику, арсенал яких поповнюється у зв'язку із соціально-економічними проблемами, несприятливим навколишнім середовищем, негативно відбиваються на ньому [2, с. 14] Багатоаспектність передумов розвитку еректильної дисфункції (ЕД) визначає його провідне місце в структурі сексуальних розладів. У контексті роботи серед таких передумов звертає увагу артеріальна гіпертензія (АГ), стійкий приріст поширеності якої відмічено в публікаціях [9, с. 4]. За даними офіційної статистики на 2011 р. в Україні на обліку перебувало понад 12 млн. таких хворих, що складає 32,2 \% дорослого населення країни $[7$, c. 22]. Ризик ускладнень при АГ зростає із кількістю супутніх факторів. Для чоловіків більш загрозливою $є$ комбінація із тютюнопалінням та ожирінням. Якщо зважити, що основними органами-мішенями $\epsilon$ серце, мозок, судини, то стає очевидним частота появи ЕД. За даними різних авторів, майже у половини хворих на АГ у віці 40-79 років спостерігаються ті чи інші ії прояви. В роботах Горпинченка I. I., 2013, Карпова Ю. А., 2010, Кузьмінова Н. В., 2015 розкриваються патогенетичні механізми простеженого взаємозв'язку. Однак, ситуацію ускладнюють демографічні зміни, що проявляються в старінні населення країни та його гендерному складі. ЕД погіршується з віком, а це набуває особливого значення з огляду на одночасне зростання й випадків АГ. Так, в Україні 40,0 \% чоловіків 40-50 років, 50,0 \% - 50-60 років та $70,0 \%$ - старших за 60 років мають ЕД [7, с. 33]. Варто наголосити на доведеній залежності між прийомом гіпотензивних препаратів при АГ та розвитком ЕД [8, с. 11]. А саме, від 2,4 \% до 58,0 \% чоловіків відмічають іiі, особливо у разі застосування діуретиків та бета-адреноблокаторів, що спонукає їх відмовитись від терапії i, тим самим погіршити прогноз перебігу захворювання [4, с. 22]. За таких умов до проблемних питань відноситься вибір адекватного лікування зазначеного контингенту пацієнтів. За даними Горпинченка I. I., Воробця Д. 3., 2011, препаратами вибору є інгібітори ангіотензинперетворюючого ферменту. Артеріальна гіпертензія (АГ) - одне з найпоширеніших хроніч- 
них захворювань людини, яка залишається однією з найактуальніших проблем сучасної медицини. За статистичними даними Міністерства охорони здоров’я, в Україні у 2003 році зареєстровано понад 9,8 млн. людей з АГ, що становить 24,3\% дорослого населення. У зв'язку 3 широкою поширеністю, підвищеним ризиком серцево-судинних захворювань, високою смертністю і відсутністю адекватного контролю, АГ є не тільки потужним чинником розвитку інфаркту міокарду, мозкового інсульту, але і робить вагомий негативний вплив на здоров'я в цілому, призводячи до ураження усіх органів і систем, викликаючи порушення еректильної функції (ЕФ) [11; 20; 27].

Сучасні погляди на розвиток сексуальних розладів у чоловіків хворих на АГ є неоднозначними. Існує ряд дискусійних позицій, які потребують подальшого глибокого вивчення з використанням новітніх методичних підходів. Отримані дані дозволять розширити спектр методів верифікації даної патології [5, с. 44]. Не менш дискусійними залишаються питання лікування хворих із застосуванням медикаментозних засобів із різними механізмами лікувальної дії, що особливо важливо у зв’язку з появою на фармакологічному ринку нових препаратів.

Вищевикладене обгрунтувало мету дослідження.

Мета дослідження: покращити діагностику сексуальних розладів у чоловіків із артеріальною гіпертензією на основі визначення особливостей ендотеліальної функції артеріальних судин та обгрунтувати ефективність удосконаленої схеми комплексного лікування еректильної дисфункції.

\section{Завдання дослідження:}

1. Визначити частоту, ступінь вираженості та особливості клінічного перебігу сексуальних розладів у чоловіків, хворих на артеріальну гіпертензію.

2. Оцінити стан ендотеліальної функції у чоловіків, хворих на артеріальну гіпертензію, які мають еректильну дисфункцію.

3. Провести порівняльний аналіз результатів лікування еректильної дисфункцї у хворих на артеріальну гіпертензію за загальноприйнятою схемою.

4. Обгрунтувати діагностичний комплекс визначення ступеня тяжкості еректильної дисфункції у чоловіків із артеріальною гіпертензією.

5. Обгрунтувати удосконалені схеми комбінованої терапії для корекції еректильної дисфункції у хворих на артеріальну гіпертензію. 
6. Довести ефективність запропонованих удосконалених комплексних схем лікування еректильної дисфункцією у чоловіків, хворих на артеріальну гіпертензію.

Об'єкт дослідження: чоловіки із сексуальними розладами, які хворіють на артеріальну гіпертензію.

Предмет дослідження: діагностика, лікування еректильної дисфункції.

Методи дослідження: загальноклінічні, анамнестичний, біохімічні, спеціальні сексологічні, ультразвукові, соціологічний та статистичний. В роботі використано бібліосемантичний, аналітикосинтетичний, компоративний аналізи.

\section{Наукова новизна одержаних результатів.}

Обгрунтовано діагностичний комплекс визначення ступеня тяжкості еректильної дисфункції у чоловіків, хворих на артеріальну гіпертензію, що складається із визначення стану кавернозних артерій до і після медикаментозної стимуляції ерекції, судиннозвужуючої функції артеріального ендотелію та рівня пептиду ендотеліального походження з вазоконстрикторною дією в крові.

Визначені межові значення величин показників пікової систолічної швидкості кавернозних артерій, діаметру плечової артерії та рівня ендотеліну-1 сироватки крові, за якими забезпечується об'єктивний розподіл чоловіків, хворих на артеріальну гіпертензію, в залежності від ступеня тяжкості еректильної дисфункції та персоніфікований підхід до вибору адекватної ії корекції.

Обгрунтовано і запропоновано удосконалені схеми комплексного лікування еректильної дисфункції у чоловіків з артеріальною гіпертензією, із включенням інгібітора фосфодіестерази 5-го типу (ФДЕ-5), донатора оксид азоту і засобу електростимуляції кавернозних артерій та виділенням варіантів режиму їх застосування з урахуванням ступеня порушення функції.

Подальшого розвитку отримало вивчення взаємозв'язку між ендотеліальною та еректильною функцією, що дозволяє отримати підтвердження значень змін показників першої як передумов розвитку другої.

\section{2. Матеріали та методи дослідження}

Базою дослідження була Івано-Франківська центральна міська клінічна лікарня: кардіологічне та урологічне відділення. Період вивчення 
склав три роки (2011-2014 рр.). Генеральна сукупність досліджуваних представлена 220 чоловіками. До неї увійшло 120 хворих з еректильною дисфункцією (ЕД) та артеріальною гіпертензією (АГ), з приводу чого були обстежені та лікувались у вказаних спеціалізованих відділеннях

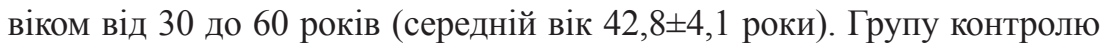
склали 100 здорових чоловіків аналогічного віку. Вона була створена 3 метою доведення змін обраних для об'єктивізації показників. Основна група (120 хворих) представляла собою суцільну вибірку і за типологічною ознакою відібрана із загальної кількості госпіталізованих хворих на АГ. Діагноз гіпертонічної хвороби (ГХ) був верифікований згідно даних обстежень, відповідно до існуючого клінічного протоколу. Протокол діагностики і лікування ГХ (наказ МОЗ України від 24.05.2012 p., № 384). Встановлено, що усі хворі, які стали об’єктом вивчення мали ГХ I-II стадії, 1-2 ступеня підвищення АТ, ризиком 2-3. Перший ступінь був у 44 хворих (36,6 \%), другий - у 55 (45,9\%), третій - у 21 (17,5 \%). До реалізації задач залучені соціологічні дослідження. Для цього використовувався опитувальник - МІЕФ. За його допомогою визначався ступінь вираженості еректильної дисфункції. Оцінка здійснювалась за п'ятибальною системою. Критеріями розподілу хворих за виділеними трьома ступенями тяжкості служили наступні граничні значення величин: тяжка (0-10 балів), середньої тяжкості (11-16 балів), легка (17-22 бали). 120 хворих за ступенем ЕД були представлені таким чином: легкий - 61; середньої тяжкості - 52; тяжкий - у 7 пацієнтів, відповідно. Варто зазначити, що даним опитувальником керувались $\mathrm{i}$ в динаміці при доведенні ефективності схем, обраних для лікування хворих на АГ із ЕД. Крім того, методом опитування, оцінювали вираженість ерекції за 4-х бальною шкалою: 1 - збільшення розміру, але відсутність твердості, 2 - недостатня твердість для введення статевого члена в піхву, 3 - досить тверда для введення статевого члена в піхву, але не повністю тверда, 4 - повністю тверда.

Щодо вікових періодів пацієнтів, то вони були такими: 30-39 років 64 чоловіки, 40-49 - 40 чоловіків, 50-59 - 16 чоловік. Вікова особливість проявилася в тому, що з віком чоловіків із тяжкою ЕД було вірогідно більше $(57,6 \pm 1,2$ роки, $\mathrm{p}<0,05)$, тоді як із середнім ступенем тяжкості вони були молодші (48,2 $\pm 0,6$ років), ще молодші ті, що мали легкий ступінь (34,3 $\pm 0,5$ років) ЕД. Ступінь ЕД пов'язана з АГ, а саме: $7,7 \pm 0,2$ роки, $3,3 \pm 0,1$ та $2,8 \pm 0,08$ років відповідно; $\mathrm{p}<0,05$. 


\section{Clinical and pathogenetic peculiarities of sexual disorders in men with...}

Дослідження виконувалось у два етапи. На першому етапі дослідження виявилося, що регулярну антигіпертензивну терапію в анамнезі отримували 71,4 \% чоловіків. Застосування гіпотензивних препаратів було наступним: $\beta$-блокатори у $29,0 \%$, ІАПФ у $81,0 \%$, антагоністи кальцію у 21,0 \%, діуретики у $12,0 \%$, комбінованої терапії дотримувались 46,0 \% пацієнтів.

На II етапі дослідження 120 хворих були розподілені в залежності від методу лікування на чотири групи по 30 чоловік. I група отримувала інгібітор фосфодіестерази-5, силденафіл «на вимогу». Пацієнтам II групи рекомендували силденафіл по 50 мг через день; III група отримувала силденафіл по 50 мг через день+аргінін; IV група - силденафіл+аргінін+ЛВТ-терапія (терапія локальним від'ємним тиском 3 фотовакуумною електростимуляцією на апараті «Лодап»). Включення до схем аргініну зумовлено тим, що L-аргінін $є$ природним попередником оксиду азоту, який впливає на функціональний стан ендотелію судин при АГ у поєднанні з ЕД. Пацієнти III та IV груп отримували дозу активної речовини аргініну 4,2% р-н по 100 мл внутрішньовенно 1 раз на добу, протягом 10 днів, потім аргінін всередину по 15 мл 2 рази на добу ще 20 днів.

Розширення методу комплексного лікування здійснювалось за рахунок ЛВТ -терапії із фотовакуумною електростимуляцією на апараті «Лодап». При цьому дотримувались проведення загальноприйнятої схеми.

Судиннозвужуючу функцію ендотелію оцінювали за допомогою ультразвукового апарату SONOS-4500 (Hewlett Packard, CША) лінійним датчиком 7 МГц в режимі триплексного сканування по методиці D. Celermajer. При цьому розраховувалися наступні параметри: 1) діаметр плечової артерії (см) - вихідний $-\mathrm{d}_{0}$, при реактивній гіперемії $-\mathrm{d}_{2}$ 2) ступінь зміни діаметра плечової артерії (\%); при реактивній гіперемії $-\Delta \mathrm{d}_{02}=\left(\mathrm{d}_{0}-\mathrm{d}_{2}\right) * 100 / \mathrm{d}_{0}$. Зменшення діаметра плечової артерії на $15 \%$ свідчила про ендотеліальну недостатність. Функціональний стан ендотелію оцінювали за концентрацією в сироватці крові ендотеліну-1 шляхом імуноферментного аналізу за допомогою набору фірми "Biomedica". Нормальні значення ендотеліну-1 з антикоагулянтом ЕДТА становили 0,00-0,25 фмоль/мл.

Доплерографію кавернозних артерій проводили на апараті “Siemens Sonoline G 60S” лінійними датчиками, що працюють у частотному діа- 


\section{Vintoniv Oksana}

пазоні 7,5-12,0 МГц. При дослідженні визначали основні доплерівські показники - максимальну систолічну швидкість (PSV), кінцеву діастолічну швидкість (EDV) та індекс резистентності (RI). Особливість методу полягала в попередньому встановленні значень відповідних показників до стимуляції ерекції, дані яких розцінювались як базові. Максимальна систолічна швидкість менше 25 см/с вважалась заниженою. Наступні дослідження проводились після інтракавернозного введення папаверину гідрохлориду в дозі 2,5 мл.

Статистична обробка отриманих даних проведена на IBM-сумісних комп'ютерах. Для зберігання та обробки результатів використовувалися програми електронних таблиць Microsoft Excel 2000 та програма статистичної обробки “STATISTICA” (v.6).

\section{3. Результати досліджень та їх обговорення}

Згідно до завдань дослідження була вивчена частота хворих на АГ, у яких виявлена ЕД у динаміці за три роки (2011-2014рр.), в результаті чого встановлена особливість, що підкреслює ії актуальність і полягає в наступному: з роками кількість госпіталізованих із АГ зменшується. Так, у 2014 р. їх було 1114 осіб, що на 17,3 \% менше, ніж три роки поспіль. Водночас, на 21,4 \% стало менше серед них й чоловіків (у 2014 р. - 411 хворий); на їх долю припадало 38,8 1,3 \% у 2011 р.

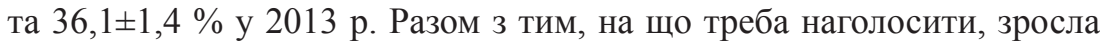
питома вага тих, у кого АГ була ускладнена ЕД: у 2011 р. вона складала $61,7 \pm 2,1 \%$, у 2013 р. $-67,2 \pm 2,3 \%(\mathrm{p}<0,05)$. Середній вік таких хворих становив 43,4 2,5 роки, що свідчить про соціальний аспект питання. Вірогідна більшість 3 них мала легкий ступінь ЕД - 59,8 4,5 \%, тоді як середній $-43,4 \pm 4,5 \%$ та тяжкий $-5,8 \pm 2,1 \%(\mathrm{p}<0,05)$. Простежена ще одна особливість. Вона проявилась у вигляді прямої залежності між віком та $з$ тяжкістю і тривалістю АГ, з вираженістю ЕД.

За даними соціологічного дослідження виявлено, що ЕД, за багатьма їі компонентами по МІЕФ, була достовірно нижча у чоловіків на фоні АГ, ніж у чоловіків групи контролю. Найбільшу відмінність відмічено в можливості досягнення ерекції; пацієнтами вона була оцінена в 2,3 $\pm 0,1$ бали, тоді як чоловіками контрольної групи $-4,7 \pm 0,3$ бали $(\mathrm{p}<0,05)$. Друга, не менш важлива, складова - іiї стійкість. За 4-х бальною характеристикою першими вона визначена в 1,0土0,07 проти

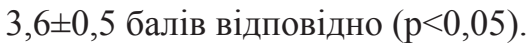




\section{Clinical and pathogenetic peculiarities of sexual disorders in men with...}

За даними доплерографії кавернозних артерій встановлено, що хворі тільки на АГ мали вірогідно нижче значення пікової систоліч-

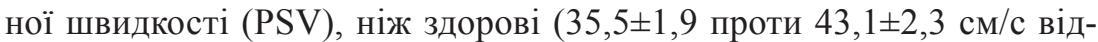
повідно; $\mathrm{p}<0,05)$. Ще меншою PSV була у випадках поєднання АГ із ЕД. Так серед обстежених пацієнтів (120 чол.) показник PSV становив $21,4 \pm 3,4 \mathrm{~cm} / \mathrm{c}$, що нижче визначеної його величини $(25 \mathrm{~cm} / \mathrm{c})$, яка оцінювалась як субклінічна ознака артеріальної еректильної дисфункції. Конкретні дані виглядають наступним чином: у 35 хворих iз АГ і ЕД PSV дорівнювала 20-24 cм/c, у $45-15-19$ см/c, у $20-$ $10-14 \mathrm{~cm} / \mathrm{c}$ і у 20 - менше $10 \mathrm{~cm} / \mathrm{c}$. Після індукції ерекції інтракавернозною ін'єкцією папаверином пікова систолічна швидкість у 72,0 \% випадків зросла до показників контрольної групи. Однак, для цього був потрібний достатньо тривалий період ( $\geq 20$ хв.), що свідчить про судинний компонент ЕД.

При дослідженні ендотеліальної функції встановлено, що 85,8 \% пацієнтів мали недостатню i, навіть, парадоксальну реакцію ендотелію. Середнє значення ендотелійзалежної вазодилятації (ЕЗВД) плечової артерії початково становило 9,8 $00,25 \%$, що в 1,5 рази менше, ніж у осіб групи контролю $(15,2 \pm 0,5 ; \mathrm{p}<0,05)$. У $14,2 \%$ не спостерігали приросту діаметру плечової артерії у відповідь на компресію (ЕЗВД мала нульове значення), в 26,4% відзначена парадоксальна реакція ендотелію - вазоконстрикція в ході проведеної проби. Приріст діаметру плечової артерії у відповідь на підвищення швидкості кровотоку після компресії виявився достовірно нижчим у хворих з АГ на фоні ЕД у порівнянні з контрольною групою. Так, у здорових діаметр плечової артерії збільшився на 16,8 $2,1 \%$, у хворих з АГ достовірно менше - на $8,2 \pm 3,4 \%(\mathrm{p}<0,05)$, а у хворих на АГ з ЕД показник був ще меншим на $7,9 \pm 1,9 \%$. Зазначене свідчить про погіршення здатності судин до вазодилятації у відповідь на механічну їх дію.

В ході дослідження також встановлено, що рівень ендотеліну-1 сироватки крові у обстежених хворих коливався від $3,2 \pm 0,1$ до $3,4 \pm 0,1$ фмоль/мл (середнє значення $3,3 \pm 0,1$ ), тоді як у практично здорових становив $0,115 \pm 2,25$ фмоль/мл, що підтверджує значні зміни ендотеліальної функції ( $<<0,05)$.

Вплив використаних схем лікування в групах у подальшому оцінювався за динамікою кількості балів МІЕФ через 1 місяць від початку лікування та через 1 місяць після його відміни. В першому випадку, 
тобто через 1 місяць від початку прийому силденафілу, середній бал за МІЕФ був вищим у II групи (23,2 бали), проти I, де показник практично не змінився $(16,5$ бали) (p $<0,05)$. Таким чином, достовірне покращення було відмічено тільки при регулярному прийомі препарату. Серед пацієнтів III групи, які приймали рекомендовану комбіновану терапію (силденафіл+аргінін), показник значно вищий у порівнянні з I групою $(24,1 \pm 0,3$ бали), ще більшим він виявився у хворих IV групи, які отримували другий варіант запропонованої терапії, а саме, силденафіл+аргінін+ЛВТ-терапія з фотовакуумною електрости-

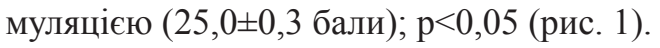

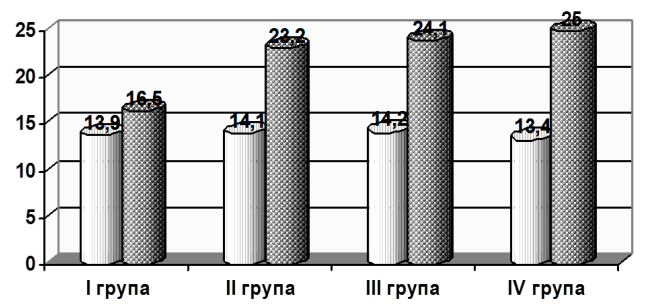

\begin{tabular}{|l|}
\hline до лікування \\
01 міс після лікування
\end{tabular}

\section{Рис. 1. Динаміка показників МІЕФ в групах до лікування та через 1 міс. від його початку (в балах)}

Примітка: * - достовірне значення між показниками до лікування та через 1 міс. від його початку, $\mathrm{p}<0,05$.

Варто наголосити на особливостях результату лікування в залежності від ступеня вираженості ЕД. При легкому та середньому їі ступенях у хворих II, III та IV груп спостереження відмічено покращення ерекції вже через 1 місяць від початку лікування, яке набуло достовірності в III та IV групах. Показники за МIЕФ становили до лікування 14,2, та 13,4 балів, після - 24,1 і 25,0 бали відповідно. Значне покращення показників МІЕФ були на фоні регулярного та комбінованого прийому препаратів (III та IV група) наступало раніше на 11,2 дні, ніж у II групі (за суб'єктивними результатами). В I групі позитивна динаміка практично відсутня $(\mathrm{p}>0,05)$.

Далі прокоментуємо результативність терапії через 1 місяць після завершення лікування. Ефективність іiі в II та III групах спостереження знижувалася із віком хворих: у чоловіків до 40 років вона досягла у 


\section{Clinical and pathogenetic peculiarities of sexual disorders in men with...}

$95,2 \pm 1,9 \%$ випадках, до 60 років - була значно меншою - 76,8 $\pm 3,8 \%$ $(\mathrm{p}<0,05)$. Ефективність комбінованої терапії силденафілом, аргініном та ЛВТ-терапією $з$ фотовакуумною електростимуляцією (IV група) також залежала від вікової категорії пацієнтів. Проте, за даними порівняльного аналізу підтверджено, що у хворих, молодших за 40 років вона була вищою - 97,8 $1 \%$, зазначена ефективність й серед хворих

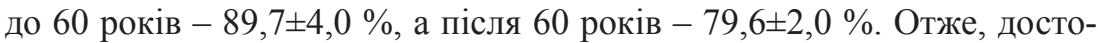
вірно кращий результат виявлено у пацієнтів IV групи, що отримували запропоновану комбіновану терапію ( $<00,05)$.

Водночас встановили, що тривалий період напіввиведення силденафілу і його тривале знаходження в плазмі крові в терапевтичних концентраціях забезпечує спонтанний статевий акт, що було актуально серед чоловіків молодого віку. Однак, прийом силденафілу та аргініну забезпечував більш стійку, сильнішу ерекцію. При курсі силденафілу, аргініну та ЛВТ-терапії з фотовакуумною електростимуляцією отримували швидший результат на фоні стійких ерекцій, що було позитивно відмічено пацієнтами. Успіх терапії також залежав від ступеня ЕД. У хворих із тяжким ступенем ЕД, ефективність силденафілу+аргініну+ЛВТ-терапії з фотовакуумною електростимуляцією була найвищою - 86,3 $\pm 1,2 \%$, порівняно з іншими групами, різниця достовірна

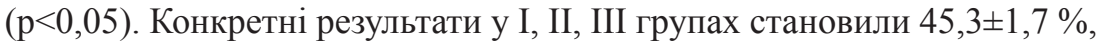
$56,8 \pm 1,7 \%, 67,3 \pm 1,6 \%$ відповідно $(\mathrm{p}<0,05)$.

В ході дослідження простежена залежність позитивного результату лікування від ступеня АГ. Кількість таких хворих 31 ступенем була

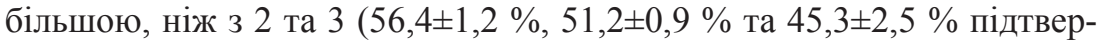
джена достовірність різниці між першою та іншими двома групами) $(\mathrm{p}<0,05)$. Далі наведемо порівняльні дані в розрізі виділених груп спостереження. Виявилось, що серед хворих 31 та 2 ступенями АГ ефект терапії був досягнутий за схемою II групи - у 65,3 $\pm 1,6 \%-$ $61,4 \pm 1,6 \%$ випадків відповідно, III $-75,8 \pm 1,4 \%-71,2 \pm 1,5 \%$ та IV $-95,6 \pm 0,7 \%$ - 91,4 $\pm 1,0 \%$, відповідно. Отже, найкращий результат отримано при запропонованих схемах, особливо із застосуванням медикаментозних препаратів разом з ЛВТ-терапією.

Як відомо, збереження лікувального ефекту після його завершення є вирішальним при оцінці того чи іншого обраного підходу. В аспекті зазначеного, наведемо інформацію отриману через 1 місяць після проведеного курсу. Встановлено, що хворі IV групи відмічали 


\section{Vintoniv Oksana}

у $80,0 \pm 1,4 \%$ відмінний та добрий ефект (у $63,5 \pm 8,8 \%$ та $19,5 \pm 7,1 \%$ відповідно; $\mathrm{p}<0,05)$; тобто, у вірогідній більшості він був відмінним, $і$ лише у кожного п'ятого - задовільний. Близькими до них були результати у хворих, які дотримувались прийому силденафілу по 50 мг через добу + аргінін (III група). Відмінний був у 15 пацієнтів $(50,0 \pm 9,1 \%$ ),

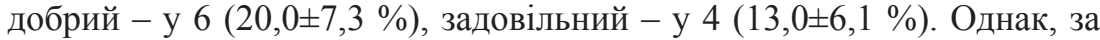
даними порівняльного аналізу перевага на боці комплексної терапії, удосконаленої ЛВТ - терапії (IV група). Адже, відмінні та добрі результати лікування в останній групі, як вказано вище, досягали $80,0 \pm 1,4 \%$, тоді як в III - у 70,0土8,3 \%. У хворих I та II груп показники виявилися гіршими, що підтверджено статистично. Зокрема, у

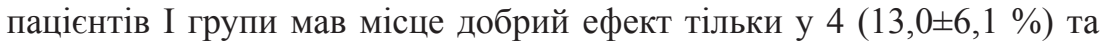

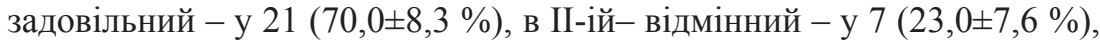

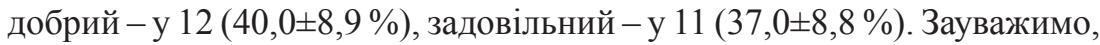
що серед пацієнтів II групи відмінний і добрий результат досягнутий в $63,0 \pm 8,8 \%$. За такою оцінкою він вірогідно поступався результатам, отриманим у хворих IV групи, проте не різнився з такими у пацієнтів III групи. Побічних ефектів протягом проведення курсу лікування не було у жодного хворого.

Вищенаведені суб'єктивні дані знайшли своє підтвердження за результатами об'єктивного обстеження. Встановлено, що пікова систолічна швидкість в кавернозних артеріях практично у половини хворих III та IV груп наближалась до унормованих значень. В I та II групах величина показника не змінилася і залишилася достовірно меншою від аналогічних показників III та IV груп, так, логічно, від іiї унормованих значень $(\mathrm{p}<0,05)$.

Два інших показника (EDV a Ri) не зазнали будь-яких змін, що $\epsilon$ цілком природним, з огляду що вони підтверджують відсутність венозної недостатності (табл. 1).

Відповідно до програми дослідження, окремим завданням обумовлена оцінка стану ендотеліальної функції у чоловіків із поєднаною патологією (АГ та ЕД). Конкретні дані результатів обстеження представлені в табл. 2.

Як видно з таблиці 2 показник ендотеліну-1 сироватки крові хворих у всіх 4-ох групах до лікування коливався від $3,1 \pm 0,05$ до 3,4 40,08 фмоль/ мл, тоді як у практично здорових становив $0,115 \pm 0,2$ фмоль/мл. Після 1 місяця від початку лікування величина показника достовірно знизи- 
Характеристика показників кольорової доплерографії кавернозних артерій через 1 місяць лікування у пацієнтів 4-ох груп після стимуляції

\begin{tabular}{|l|c|c|c|c|}
\hline \multicolumn{1}{|c|}{$\begin{array}{c}\text { Показники } \\
\text { кольорової } \\
\text { доплерографії }\end{array}$} & $\begin{array}{c}\text { I група } \\
(\mathbf{n = 3 0 )}\end{array}$ & $\begin{array}{c}\text { II група } \\
\mathbf{( n = 3 0 )}\end{array}$ & $\begin{array}{c}\text { III група } \\
\mathbf{( n = 3 0 )}\end{array}$ & $\begin{array}{c}\text { IV група } \\
\text { (n=30) }\end{array}$ \\
\hline $\begin{array}{l}\text { PSV (пікова систо- } \\
\text { лічна швидкість), см/с }\end{array}$ & $16,5 \pm 5,6^{\Delta}$ & $19,5 \pm 3,3^{\Delta}$ & $35,3 \pm 2,7^{*}$ & $39,2 \pm 2,6^{*}$ \\
\hline $\begin{array}{l}\text { EDV (пікова діасто- } \\
\text { лічна швидкість), см/с }\end{array}$ & $4,1 \pm 0,26^{\Delta}$ & $4,3 \pm 0,19^{\Delta}$ & $4,2 \pm 0,23^{\Delta}$ & $5,0 \pm 0,19^{\Delta}$ \\
\hline $\begin{array}{l}\text { RI (індекс резистент- } \\
\text { ності) }\end{array}$ & $0,71 \pm 0,29^{\Delta}$ & $0,78 \pm 0,24^{\Delta}$ & $0,72 \pm 0,25^{\Delta}$ & $0,83 \pm 0,21^{\Delta}$ \\
\hline
\end{tabular}

Примітка: * - достовірна різниця між величинами III та IV до I та II груп; $\Delta_{-}$достовірної різниці між величинами III та IV до I та II груп не було

Таблиця 2 Динаміка змін рівня ендотеліну-1 за період дослідження, фмоль/мл

\begin{tabular}{|l|c|c|c|c|}
\hline $\begin{array}{c}\text { Показники рівня } \\
\text { ендотеліну-1 сироватки } \\
\text { крові до лікування, } \\
\text { фмоль/мл }\end{array}$ & $\begin{array}{c}\text { I група } \\
\text { (n=30) }\end{array}$ & $\begin{array}{c}\text { II група } \\
\text { (n=30) }\end{array}$ & $\begin{array}{c}\text { III група } \\
\text { (n=30) }\end{array}$ & $\begin{array}{c}\text { IV група } \\
\text { (n=30) }\end{array}$ \\
\cline { 2 - 5 } & $3,4 \pm 0,08$ & $3,2 \pm 0,06^{*}$ & $3,1 \pm 0,05^{*}$ & $3,4 \pm 0,06^{*}$ \\
\hline $\begin{array}{l}\text { Через 1 міс. від початку } \\
\text { лікування, фмоль/мл }\end{array}$ & $3,3 \pm 0,07$ & $2,9 \pm 0,05^{* * \Delta}$ & $2,7 \pm 0,07^{\Delta * *}$ & $1,4 \pm 0,07^{\Delta * *}$ \\
\hline $\begin{array}{l}\text { Через 1 міс. після відміни } \\
\text { терапії фмоль/мл, }\end{array}$ & $3,3 \pm 0,05$ & $2,9 \pm 0,06$ & $2,1 \pm 0,05$ & $0,84 \pm 0,09^{\Delta}$ \\
\hline
\end{tabular}

Примітка: */ - показники II, III груп достовірно менші, а IV більші, ніж в I групі; **/ - різниця достовірна між показниками до та після лікування; ${ }^{\Delta} /$ - показники достовірні між групами.

лась у пацієнтів III та IV груп. Варто наголосити, що впродовж місяця після завершення курсу показники ендотеліну-1 продовжували зменшуватися в III та IV групах. В результаті, серед останніх, вони практично досягли значень практично здорових чоловіків $(0,84 \pm 0,09$ фмоль/ мл), а у III вірогідно знизились до показників щодо останніх, які були при попередньому обстежені - через 1 місяць від початку лікування $(2,1 \pm 0,05$ проти $2,7 \pm 0,07)$, відповідно ( $<<0,05)$. В II групі динаміка позитивних змін була меншою. Достовірною різниця виявилась між показниками до та через місяць від початку лікування $(3,2 \pm 0,06$ та $2,9 \pm 0,05)$, відповідно, проте надалі залишалась на цьому ж рівні. Звер- 


\section{Vintoniv Oksana}

тає увагу, що у хворих I групи будь-яких значимих змін в показниках не спостерігалося. Підсумовуючи, відмітимо, що найбільший позитивний ефект досягнуто в IV групі, оскільки тільки серед цих пацієнтів відповідні показники стали наближеними до норми. За результатами поглибленого вивчення простежена залежність між вираженістю змін ендотеліальної функції та тяжкістю ЕД.

Зокрема, при легкому ступені ЕД рівень ендотеліну-1 дорівнював $1,3 \pm 0,5$, середньому $-2,4 \pm 0,6$, тяжкому $-3,5 \pm 0,4$ фмоль/мл $(\mathrm{p}<0,05)$. Отримані дані підтверджені також за порівняльним аналізом співставлення середніх величин посткомпресійного збільшення діаметру плечової артерії до та через місяць від припинення лікування (рис. 2).

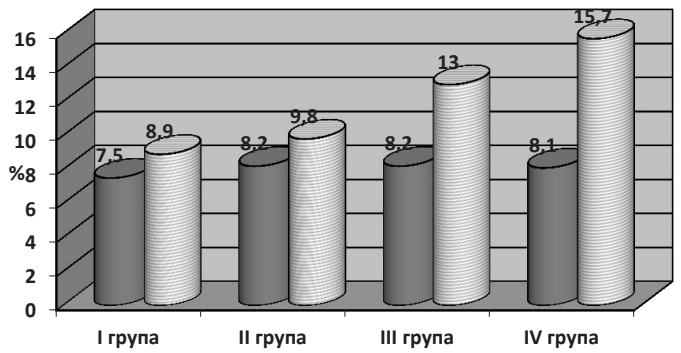

Рис. 2. Динаміка змін показників системної ендотеліальної дисфункції за період дослідження, \%

Примітка - * достовірна різниця показників до лікування та 1 міс. після лікування, $\mathrm{p}<0,05$.

Як видно, на рисунку 2, до лікування значення показників практично однакові, не набули вони достовірної різниці й після терапії в I та II групах $(7,5 \pm 2,1 \%$ та $8,9 \pm 1,9 \%$, (p > 0,05) та $8,2 \pm 1,7 \%$ та $9,8 \pm 2,8 \%$, (p > 0,05) відповідно). Показники відсоткового збільшення діаметру плечової артерії після лікування були притаманні тільки хво-

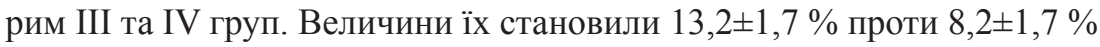
та $15,7 \pm 3,1 \%$ проти 8,2 $2,2 \%$, (p > 0,05) відповідно. Варто підкреслити, що у 25 із 120 хворих (20,8 \%) до кінця лікування вдалося збільшити посткомпресійний діаметр плечової артерії до нормальних величин, із них 67 \% (17 пацієнтів) та 33 \% (8) отримували лікування за варіантами схем IV та III груп спостереження. 


\section{Clinical and pathogenetic peculiarities of sexual disorders in men with...}

Вищенаведені результати дозволяють об'єктивізувати переваги запропонованого комплексного лікування хворих на АГ, які мають ЕД, удосконаленого за рахунок розширення схем включенням аргініну та ЛВТ-терапії з фотовакуумною електростимуляцією, що зумовлено позитивним впливом препарату на патогенетичні ланки розвитку ЕД у хворих на АГ. Дані твердження підтверджують можливість реалізувати персоніфікований підхід до вибору схеми корекції сексуальних розладів у чоловіків, хворих на АГ в залежності від їх віку, клінічного перебігу гіпертензії, ступеня вираженості сексуальної активності.

\section{4. Висновки}

У дослідженні наведено узагальнення та нове вирішення актуальної наукової задачі - покращити якість діагностики сексуальних розладів у чоловіків, хворих на артеріальну гіпертензію, на основі визначення стану ендотеліальної функції артеріальних судин організму, стану кавернозних артерій та рівня пептиду ендотеліального походження 3 вазоконстрикторною дією в крові, що забезпечує підвищення ефективності лікування за допомогою персоніфікованого підходу до вибору адекватної схеми із запропонованих удосконалених варіантів, що має суттєве значення для урології.

1. Встановлено, що на фоні зменшення загальної кількості госпіталізованих з приводу артеріальної гіпертензії (на 17,3% з 2011 по 2014 роки осіб) з однозначним зменшенням серед них чоловіків (на 21,4 \% у 2014 р.) вірогідно зростає відсоток тих, хто має ерек-

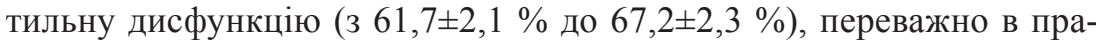
цездатному віці (середній вік $43,4 \pm 2,5$ роки). Простежена лінійна залежність між віком та тяжкістю і тривалістю артеріальної гіпертензії, а також вираженістю еректильної дисфункції; у вірогідній більшості був легкий іiї ступінь - 59,8 $\pm 4,5 \%$, середній мали $-43,4 \pm 4,5 \%$, тяжкий $-5,8 \pm 2,1 \%$.

2. Виявлено, що у $85,8 \%$ хворих на артеріальну гіпертензію із еректильною дисфункцією має місце погіршення стану ендотеліальної функції артеріальних судин, що підтверджено достовірним зменшенням ендотелійзалежної вазодилятації плечової артерії $(9,8 \pm 0,25$ \% проти 15,2 $\pm 0,5$ \% у контрольній групі), а також значним підвищенням рівня ендотеліну- 1 сироватки крові (в середньому $3,3 \pm 0,1$ проти $0,115 \pm 0,2$ фмоль/мл у групі контролю); $\mathrm{p}<0,05$. 


\section{Vintoniv Oksana}

3. Підтверджено значення судинного компоненту в патогенезі розвитку еректильної дисфункції у хворих на артеріальну гіпертензію у вигляді порушення локального кровоплину в статевому члені. Виявлено, що за наявності тільки артеріальної гіпертензії значення пікової систолічної швидкості вірогідно менше, ніж у практично здорових $(35,5 \pm 1,9$ проти $43,1 \pm 2,3 \mathrm{~cm} / \mathrm{c})$, тоді як у випадках поєднаної патології показник був удвічі меншим $(21,4 \pm 3,4 \mathrm{~cm} / \mathrm{c}) ; \mathrm{p}<0,05$.

4. Обгрунтовано удосконалений комплекс діагностики ступеня тяжкості еректильної дисфункції у чоловіків із артеріальною гіпертензією, суть якого полягає у визначенні межових значень: зменшення приросту діаметру плечової артерії після компресії (на $\leq 15 \%$ ) максимальної систолічної швидкості кровоплину в кавернозних артеріях $(\leq 25 \mathrm{~cm} / \mathrm{c})$, підвищенні рівня ендотеліну-1 сироватки крові в 1, 2, 3 рази від норми в залежності від клінічного перебігу.

5. Виявлена залежність позитивного результату лікування від ступеня артеріальної гіпертензії, вираженості порушення еректильної дисфункції та віку хворих. У пацієнтів з артеріальною гіпертензією I та II ступенів ефективність за застосованими схемами складала $65,3 \pm 1,6 \%-61,4 \pm 1,6 \%$ (II), 75,8 $\pm 1,4-71,2 \pm 1,5 \%$ (III) та 95,6 $\pm 0,7-$ $91,4 \pm 1,0$ \% (IV); при легкому та середньому ступені ЕД серед хворих II, III та IV груп спостереження через місяць лікування об'єктивізовані позитивні зміни, які в двох останніх набули достовірності (до лікування 14,2 балів, після - 24,1; до лікування 13,4 після - 25,0 балів, відповідно); у чоловіків до 40 років ефективність лікування в II-III гру-

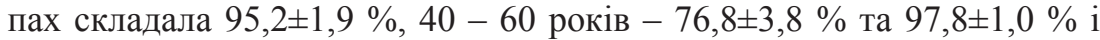
$89,7 \pm 4,0 \%$, відповідно, в IV групі, $\mathrm{p}<0,05$.

6. Обгрунтований персоніфікований підхід до вибору адекватної до віку чоловіків, ступеня артеріальної гіпертензії та вираженості еректильної дисфункції схеми лікування, що забезпечує досягнення максимальної корекції сексуальних порушень.

\section{5. Практичні рекомендації}

1. Для оцінки клініко-функціональних змін у чоловіків з сексуальними розладами, хворих на артеріальну гіпертензію доцільно в комплекс діагностичних методів включити дослідження судиннорухової функції ендотелію (за методикою D. Celejmajer) та визначення рівня ендотеліну-1 в сироватці крові. Дані показники також можуть бути 
використані як для прогнозування перебігу захворювання так i для моніторингу ефективності проведеної терапії.

2. Повноцінним та доступним методом діагностики та контролем за лікуванням чоловіків з еректильною дисфункцією хворих на артеріальну гіпертензію $є$ кольорова доплерографія кавернозних артерій 3 індукцією ерекції з визначенням показників пікової систолічної швидкості, пікової діастолічної швидкості та індексу резистентності, що дає можливість визначити судинний компонент еректильної дисфункції, вибрати тактику та оцінити ефективність лікування таких хворих.

3. Для досягнення вираженого терапевтичного ефекту у лікуванні чоловіків з сексуальними розладами, хворих на артеріальну гіпертензію, доцільно включати в комплекс лікування препарат аргінін (тівортін) та сеанси терапії локальним від'ємним тиском 3 фотовакуумною електростимуляцією. Дозою, що рекомендується для аргініну є 4,2 \% p-н (тівортіну) по 100 мл внутрішньовенно 1 раз на добу протягом 10 днів, а потім аргінін (тівортіну аспартат) всередину по 15 мл х 2 рази на добу ще 20 днів. Сеанси терапії локальним від'ємним тиском 3 фотовакуумною електростимуляцією на апараті «ЛОДАП» - через день по 10 хвилин, курсом лікування 15 процедур.

4. Застосування силденафілу, аргініну та терапії локальним від'ємним тиском $з$ фотовакуумною електростимуляцією у чоловіків з сексуальними розладами хворих на АГ призводить до покращення перебігу захворювання є безпечним, доступним і не супроводжується побічними ефектами.

\section{Список літератури:}

1. Верткин А. Л. Блокаторы рецепторов 1-го типа ангиотензина II и эректильная функція / А. Л. Верткин, Ф. А. Вилковыский, А. С. Скотников // Здоровье мужчины. - 2011. - № 3. - С. 59-63.

2. Бойко М. I. Сучасні уявлення про механізм ерекції / М. I. Бойко // Урологія. -2010. - № 1. - С. 99-104.

3. Бойко Н. И 2-ой международный конгресс по эректильной и сексуальной дисфункции / Н. И. Бойко // Здоровье мужчины. - 2010. - № 3. - С. 141-146.

4. Литвинець С. А. Сучасні погляди на етіопатогенез та напрямки лікування сексуальних розладів у чоловіків хворих на артеріальну гіпертензію / Є. А. Литвинець, О. Р. Вінтонів // Галицький лікарський вісник. - 2011. № 3. - C. 129-132. 


\section{Vintoniv Oksana}

5. Литвинець Є. А. Кольорова доплерографія, як метод обстеження сексуальних розладів у чоловіків з артеріальною гіпертензією / Є. А. Литвинець, О. Р. Вінтонів // Галицький лікарський вісник. - 2013. - № 1. - С. 34-36.

6. Литвинець Є. А. Дослідження ефективності комбінованого лікування еректильної дисфункції у пацієнтів з артеріальною гіпертензією / Є. А. Литвинець, О. Р. Вінтонів // Актуальні проблеми сучасної медицини: Вісник Української медичної стоматологічної академії. -2013. -№ 3.-С. 44-49.

7. Литвинець $€$. А. Оцінювання функціонального стану ендотелію судин у чоловіків з еректильною дисфункцією на фоні артеріальної гіпертензії в процесі комбінованої терапії / Є. А. Литвинець, О. Р. Вінтонів // Здоровье мужчины. - 2014. - № 2. - С. 116-119.

8. Lytvynets Ye. Combined Therapy of the Erectile Dysfuntion in Patients with Arterial Hypertension / Ye. Lytvynets, O. Vintoniv // The pharma innovation journal. - 2013. - Vol.2 № 9. - P. 10-13.

9. Lytvynets Ye. Effectiveness and safety of combinedtreatment of the erectile dysfunction in patient with arterial hypertension / Ye. Lytvynets, O. Vintoniv // British journal of science, education ad culture. - 2014. - № 1. - P. 326-330.

\section{References:}

1. Vertkyn A. L. (2011) Blokatory retseptorov 1-ho typa anhyotenzyna II y erektylnaia funktsiia [Blockers of type 1 receptors of angiotensin II and erectile function] Men's health. - 2011, vol 3, pp. 59-63.

2. Boiko M. I. (2010) Suchasni uiavlennia pro mekhanizm erektsii [Modern understanding of the mechanism of erection] Urology -2010, vol 1, pp. 99-104.

3. Boiko N. Y. (2010) 2-oi mezhdunarodnыi konhress po erektylnoi y seksualnoi dysfunktsyy [2nd International Congress on Erectile and Sexual Dysfunction] Men's health. - 2010, vol 3, pp. 141-146.

4. Lytvynets Ye. A. (2011). Suchasni pohliady na etiopatohenez ta napriamky likuvannia seksualnykh rozladiv u cholovikiv khvorykh na arterialnu hipertenziiu. [Modern views on etiopathogenesis and trends of treatment of sexual disorders in men with arterial hypertension] Galician Medicinal Herald.- 2011, vol 3, pp. 129-132.

5. Lytvynets Ye. A. (2013) Kolorova doplerohrafiia, yak metod obstezhennia seksualnykh rozladiv u cholovikiv z arterialnoiu hipertenziieiu. [Color Doppler, as a method of examining sexual dysfunction in men with arterial hypertension]. Galician Medicinal Herald. - 2013, vol 1, pp. 34-36.

6. Lytvynets Ye. A. (2013) Doslidzhennia efektyvnosti kombinovanoho likuvannia erektylnoi dysfunktsii u patsiientiv z arterialnoiu hipertenziieiu. [The study of the effectiveness of combined treatment of erectile dysfunction in patients with arterial hypertension] Galician Medicinal Herald - 2013, vol 3, pp. 44-49.

7. Lytvynets Ye. A. (2014) Otsiniuvannia funktsionalnoho stanu endoteliiu sudyn u cholovikiv z erektylnoiu dysfunktsiieiu na foni arterialnoi hipertenzii $\mathrm{v}$ protsesi kombinovanoi terapii [Estimation of the functional status of vascular endothelium in men with erectile dysfunction against the background of arterial hypertension in the process of combined therapy] Men's health.- 2014, vol 2, pp. 116-119. 
8. Lytvynets Ye. (2013) Combined Therapy of the Erectile Dysfuntion in Patients with Arterial Hypertension. The pharma innovation journal. - 2013. - 2(9): 10-13.

9. Lytvynets Ye. (2014) Effectiveness and safety of combinedtreatment of the erectile dysfunction in patient with arterial hypertension. British journal of science, education ad culture. - 2014. - 1: 326-330.

\section{Перелік умовних скорочень:}

ЕФ - еректильна функція

ЕД - еректильна дисфункція

ЕФ - еректильна функція

ЕТ-1 - ендотелін-1

MIIF(MIEФ) - Міжнародна система бальної оцінки симптомів еректильної дисфункції

ЛВТ-терапія - терапія локальним від’ємним тиском з фотовакуумною електростимуляцією

AГ - артеріальна гіпертензія

PSV - пікова систолічна швдкість

IR - індекс резистентності

ЕНВД - ендотелійнезалежна вазодилятація

ЕЗВД - ендотелійзалежна вазодилятація

ФДЕ-5 - фосфодіестераза-5 